\title{
Mortality in a cohort of licenced pesticide applicators in Florida
}

\author{
Lora E Fleming, Judy A Bean, Mark Rudolph, Kara Hamilton
}

\begin{abstract}
Objectives-Although the primary hazard to humans associated with pesticide exposure is acute poisoning, there has been considerable concern surrounding the possibility of cancer and other chronic health effects in humans. Given the huge volume of pesticides now used throughout the world, as well as environmental and food residue contamination leading to chronic low level exposure, the study of possible chronic human health effects is important.
\end{abstract}

Methods-This was a retrospective cohort study, analysed by general standardised mortality ratio (SMR) of licenced pesticide applicators in Florida compared with the general population of Florida. A cohort of 33658 (10\% female) licenced pesticide applicators assembled through extensive data linkages yielded 1874 deaths with 320250 person-years from 1 January 1975 to 31 December 1993.

Results-The pesticide applicators were consistently and significantly healthier than the general population of Florida. As with many occupational cohorts, the risks of cardiovascular disease and of diseases associated with alcohol and tobacco use were significantly lower, even in the subpopulations-for example, men, women, and licence subcategories. Among male applicators, prostate cancer mortality (SMR 2.38 (95\% confidence interval (95\% CI) 1.83 to 3.04$)$ ) was significantly increased. No cases of soft tissue sarcoma were confirmed in this cohort, and nonHodgkin's lymphoma was not increased. The number of female applicators was small, as were the numbers of deaths. Mortality from cervical cancer and breast cancer was not increased. Additional subcohort and exposure analyses were performed.

Conclusions-Consistent with previous publications on farmers but at odds with current theories about the protective effects of vitamin $D$, prostate cancer was increased in these pesticide applicators. Female breast cancer was not increased despite theories linking risk of breast cancer with exposure to oestrogen disruptors-such as the organochlorines. The lack of cases of soft tissue sarcoma is at odds with previous publications associating the use of the phenoxy herbicides with an increased risk of these cancers.

(Occup Environ Med 1999;56:14-21)

Keywords: prostate cancer; farmers; pesticide applicators
Exposure to pesticides has become ubiquitous to workers and the general public due to increasing and extensive applications, and environmental contamination. The acute health effects of pesticides in humans are well documented, and possibly underreported under current surveillance systems; chronic health effects are currently being investigated. ${ }^{1-9}$ The most obvious groups in which to study the chronic effects of pesticides in humans are those occupational groups who apply pesticides in high doses as part of their daily activities. Genotoxicity studies and some recent epidemiological studies in the occupationally exposed populations point to the real possibility of carcinogenic health effects in humans exposed to pesticides. ${ }^{124-610-12}$

Despite various methodological issues, , $^{510^{13-19}}$ conclusions can be drawn from the aggregate of available chronic disease studies in worker populations exposed to pesticides. Farmers, manufacturers, and pesticide applicators, the main worker groups that have been studied (with obvious overlap between them), tend to be healthier than the general population, especially for cardiovascular disease and the diseases associated with heavy tobacco and alcohol use. They are at increased risk from accidents, some of this may possibly be related to pesticides-for example, aerial sprayers. Farmers are more likely to die from infectious and non-malignant respiratory diseases; certain pesticides have immunological effects and pesticide exposure may contribute towards these disease risks, although this issue has not been studied thoroughly. ${ }^{12}$ 4-6 $^{10-12} 20$

Pesticide applicator groups (as opposed to farmers) have a higher risk of cancer than the general population and other worker groups in most studies. The worker populations exposed to the phenoxy acids and other herbicides may be at increased risk for soft tissue sarcoma and non-Hodgkin's lymphoma. Increased risk of skin cancer is found, but may be unrelated to pesticide exposure (UV exposure). Brain cancer seems to be increased, not only in these populations, but possibly in their offspring. Farmers consistently have shown increased risks of leukaemia, multiple myeloma, and prostate cancer. Pesticide applicators and manufacturing workers exposed to arsenic are at risk of lung cancer. Testicular cancer may also be increased in pesticide applicators. Both farmers and pesticide applicators can have increased risks of stomach cancers. ${ }^{4-6152122}$

This study is a standardised mortality ratio (SMR) study of general and cancer mortality in a large cohort of licenced pesticide applicators in the state of Florida. 


\section{Methods}

Under the United States Environmental Protection Agency (USEPA) since 1970, the Federal Insecticide, Fungicide, and Rodenticide Act (FIFRA) requires that people who buy or use the roughly 125 restricted use pesticides must be certified as competent pesticide applicators or must be directly supervised by a certified applicator. Persons who are not certified pesticide applicators may not purchase or use restricted pesticides unless directly supervised by a certified applicator (up to 15 people per certified applicator). Certification requires training and written testing for competency in the safe and effective handling and use of these pesticides. Licences are renewed every 4 years based on continuing education credits or a written examination. Private applicators are people who use or supervise the use of restricted use pesticides in agriculture on property owned or rented by themselves or their employer. Examples of private applicators are: farmers, ranchers, and horticulturists. Commercial applicators are people who use restricted use pesticides for hire on property other than their own full time, and government workers (public applicators) who apply pesticides as a major component of their jobs.

The core database for this study was the list of pesticide applicators licensed in the State of Florida by the Florida Department of Agriculture and Consumer Services (DACS) from 1 January 1975 to 31 December 1993. This database included name, social security number, and address, but the date of birth was missing for about $50 \%$ of the cohort, predominantly those licensed before 1982. To locate additional important information (date of birth, date of death, and incident cancer), various algorithms were linked with other available databases, including the Florida cancer data system (FCDS), Florida Department of Motor Vehicles, the Florida death tapes (from the Division of Vital Statistics), the Florida Agency for Healthcare Administration (AHCA), and the Agency for Healthcare Financing (HCFA), as well as two commercial groups Equifax and Epidemiologic Resources. The first three databases were linked with the entire pesticide applicator database, whereas the other four databases, due to limited resources, were only linked for possible cases lost to follow up .

The SMR analyses were performed for all male applicators, all female applicators, private male applicators, and male commercial and public applicators. The external comparison population was the population of Florida created from the Florida death tapes. The death tape data of Florida deaths were incomplete for 1993; therefore only 1990-2 deaths and population were used to calculate the disease specific death rates from 1990-3.

The age adjusted SMRs were calculated according to the method of Breslow and Day. ${ }^{23}$ The SMR and 95\% confidence intervals (95\% CIs) were calculated by the method of Rothman and Boice, ${ }^{24}$ assuming a constant denominator. ${ }^{25} 26$ Person-years started on the first calendar year and month of licence, and ended with the earliest date of death, the end of the study period, or 4 years after the most recent licence date. The age and calendar year groupings were in 5 year sets, starting in 1975 with age $\geqslant 20$. All statistical analyses were performed with SAS version 6.11.

\section{Results}

From the 39090 original licences, social security number and name were used to identify 37072 unduplicated licences. Any licence without a date of birth $(n=2664)$, missing information including sex (386), date of death, or licence before 18 years of age (21), or with an out of state death (51) was excluded from the final cohort due to limited resources; most $(>95 \%)$ of those people with missing information had obtained their licence before 1980 and had not relicensed after the initial 4 year licence period.

After the data linkages, 34211 (92\%) unique people had complete information. From this total cohort, there were 33658 applicators aged $\geqslant 20$ years with 1874 deaths. Of the 1874 deaths, 1855 had an international classification of diseases (ICD) code that allowed cause of death subgroup analysis. Most of these deaths (55\%) had taken place by 1989 . The total number of person-years for the entire cohort was 320250 from 1 January 1975 to 31 December 1993.

Of these, there were 3503 (10\%) women and $30155(90 \%)$ men (table 1). Using the last name to assign ethnic origin, only 1362 (4\%) of the cohort were Hispanic. Information on race was only available for 7417 (22\%) of the cohort (predominantly the deaths and incident cancer cases); most of these people (97\%) were white.

The mean (SD) age at issue of first licence was 39.26 (13.19) with a range of 18 to 89 years; the mean age at first licence for the women was significantly younger than for men $(p<0.0001$, table 2). The mean (SD) number of years licensed was 6.93 (4.27) with a range of 1 month to 19.64 years; for the women, the mean number of years licensed was significantly less than for the men $(p<0.0001)$.

Of the different types of licence, 22873 $(68 \%)$ were private, 7591 (23\%) commercial, and $3194(9 \%)$ public. As shown in table 2, those people with a private licence were significantly older at first licence $(41.43(13.66))$ and at death (67.57 (12.52), $\mathrm{p}<0.0001)$; this group was licensed on average significantly longer (7.52 (4.38)) than the commercial and public licence groups $(\mathrm{p}<0.0001)$.

Table 1 Sex and licence distributions

\begin{tabular}{lrrr}
\hline & Female & Male & Total \\
\hline Entire cohort: & & & \\
Private & 2522 & 20505 & 22873 \\
Commercial & 596 & 6936 & 7591 \\
Public & 385 & 2714 & 3194 \\
$\quad$ Total & 3503 & 30155 & 33658 \\
All deaths: & & & \\
$\quad$ Private & 86 & 1527 & 1613 \\
Commercial & 7 & 165 & 172 \\
Public & 5 & 85 & 90 \\
Total & 98 & 1777 & 1875 \\
\hline
\end{tabular}


Table 2 Means of age at licence, duration of time licensed, age at death by sex, and type of licence

\begin{tabular}{|c|c|c|c|c|c|c|c|c|}
\hline & $\begin{array}{l}\text { Female mean } \\
(S D)\end{array}$ & $\begin{array}{l}\text { Male mean } \\
(S D)\end{array}$ & $\begin{array}{l}\text { Total mean } \\
(S D)\end{array}$ & $p$ Value ${ }^{*}$ & $\begin{array}{l}\text { Private mean } \\
(S D)\end{array}$ & $\begin{array}{l}\text { Commercial or } \\
\text { public mean } \\
(S D)\end{array}$ & $\begin{array}{l}\text { Total mean } \\
(S D)\end{array}$ & $p$ Value ${ }^{\star}$ \\
\hline \multicolumn{9}{|l|}{ Cohort: } \\
\hline $\begin{array}{l}\text { Mean age first } \\
\text { licence }\end{array}$ & $37.68(12.32)$ & $39.45(13.27)$ & $39.26(13.19)$ & 0.0001 & $41.42(13.65)$ & $35.91(10.59)$ & $39.26(13.19)$ & 0.0001 \\
\hline $\begin{array}{l}\text { Mean years } \\
\text { licensed }\end{array}$ & $5.47(3.04)$ & $7.09(4.36)$ & $6.93(4.27)$ & 0.0001 & $7.52(4.38)$ & $5.68(3.74)$ & $6.93(4.27)$ & 0.0001 \\
\hline Mean age at death & $62.43(15.45)$ & $66.12(13.52)$ & $65.92(13.65)$ & 0.02 & $67.55(12.52)$ & $55.31(12.59)$ & $65.92(13.65)$ & 0.0001 \\
\hline $\begin{array}{l}\text { All deaths: } \\
\text { Mean age first } \\
\text { licence }\end{array}$ & $53.37(13.26)$ & $56.55(12.35)$ & $56.38(12.42)$ & 0.02 & & & & \\
\hline $\begin{array}{l}\text { Mean years } \\
\text { licensed }\end{array}$ & $7.27(2.73)$ & $8.23(2.99)$ & $8.18(2.98)$ & 0.001 & & & & \\
\hline Mean age at death & $62.43(15.45)$ & $66.12(13.52)$ & $65.92(13.65)$ & 0.02 & & & & \\
\hline
\end{tabular}

lation of Florida (0.78 (0.72 to 0.86)). In general, most cancer mortalities were lower for the male pesticide applicators than the population of Florida. Cancers associated with tobacco exposure-such as respiratory and lung cancers-were lower (although not significantly). The exceptions to this were increased cancer mortalities for the eye, bone, prostate, brain and CNS, leukaemia, and liver; only prostate cancer (2.38 (1.83 to 3.04)) was significantly increased, and there were only three cases each of eye and bone cancer.

eral population of Florida (SMR $0.72(95 \%$ CI 0.69 to 0.75$)$ ). Non-cancer causes of death were all less than those that of the population of Florida. In particular, causes of death associated with exposure to alcohol-such as cirrhosis- $(0.49$ (0.32 to 0.72$))$ were significantly lower, as with exposure to tobaccosuch as emphysema- $0.71(0.38-1.22))$. External causes were non-significantly lower. The greatest single cause of death was from circulatory diseases $(44 \%)$, but the SMR for all the diseases of the circulatory system was significantly lower.

The SMR for all malignancies was significantly lower compared with the general popu-

Table 3 Male and female applicators: overall and non-cancer SMR

\begin{tabular}{|c|c|c|c|c|}
\hline \multirow[b]{2}{*}{ Cause of death } & \multicolumn{2}{|l|}{ Male } & \multicolumn{2}{|l|}{ Female } \\
\hline & Observed $n$ & Florida SMR $(95 \%$ CI) & Observed $n$ & Florida SMR $(95 \%$ CI) \\
\hline Overall & 1776 & $0.72(0.69 \text { to } 0.75)^{\star}$ & 98 & $0.44(0.36 \text { to } 0.54)^{\star}$ \\
\hline Infectious diseases & 35 & $0.52(0.36 \text { to } 0.73)^{\star}$ & 2 & $0.64(0.07$ to 2.30$)$ \\
\hline Tuberculosis & 2 & $0.64(0.07$ to 2.30$)$ & 0 & $1.69(0.01$ to 15.72$)$ \\
\hline Allergic endocrine & 32 & $0.56(0.38 \text { to } 0.78)^{\star}$ & 2 & $0.36(0.04$ to 1.30$)$ \\
\hline Diabetes & 26 & $0.61(0.40 \text { to } 0.89)^{\star}$ & 0 & $0.12(0.00$ to 1.15$)$ \\
\hline Diseases of blood & 6 & $0.78(0.29$ to 1.71$)$ & 0 & $0.66(0.00$ to 6.17$)$ \\
\hline Mental & 10 & $0.48(0.23 \text { to } 0.88)^{\star}$ & 0 & $0.24(0.00$ to 2.28$)$ \\
\hline Nervous system & 34 & $1.15(0.80$ to 1.61$)$ & 1 & 0.35 (0.01 to 1.94$)$ \\
\hline Circulatory system & 765 & $0.85(0.80 \text { to } 0.92)^{\star}$ & 26 & $0.33(0.21 \text { to } 0.48)^{\star}$ \\
\hline Rheumatic HD & 5 & $0.60(0.19$ to 1.39$)$ & 0 & $0.64(0.00$ to 5.97$)$ \\
\hline ASHD (w/CHD) & 498 & $0.97(0.89$ to 1.06$)$ & 12 & $0.26(0.14 \text { to } 0.46)^{\star}$ \\
\hline AHD & 536 & 0.94 (0.86 to 1.02$)$ & 15 & $0.29(0.16 \text { to } 0.48)^{\star}$ \\
\hline $\begin{array}{l}\text { Central nervous system } \\
\text { vascular }\end{array}$ & 90 & $0.81(0.65$ to 1.00$)$ & 6 & $0.57(0.21$ to 1.24$)$ \\
\hline Respiratory diseases & 53 & $0.63(0.47 \text { to } 0.83)^{\star}$ & 5 & $0.62(0.20$ to 1.46$)$ \\
\hline Pneumonia & 19 & $0.54(0.33 \text { to } 0.85)^{\star}$ & 5 & $1.46(0.47$ to 3.42$)$ \\
\hline Emphysema & 13 & $0.71(0.38$ to 1.22$)$ & 0 & $0.29(0.00$ to 2.73$)$ \\
\hline Asthma & 1 & $0.23(0.01$ to 1.27$)$ & 0 & $1.18(0.00$ to 10.98$)$ \\
\hline Digestive diseases & 55 & $0.61(0.46 \text { to } 0.80)^{\star}$ & 1 & $0.12(0.01 \text { to } 0.67)^{\star}$ \\
\hline Ulcers & 6 & $1.09(0.40$ to 2.36$)$ & 1 & $1.91(0.03$ to 10.64$)$ \\
\hline Cirrhosis & 25 & $0.49(0.32 \text { to } 0.72)^{\star}$ & 0 & $0.11(0.00$ to 1.02$)$ \\
\hline Genito urinary & 17 & $0.77(0.45$ to 1.22$)$ & 1 & $0.47(0.01$ to 2.61$)$ \\
\hline Skin diseases & 1 & $0.41(0.01$ to 2.28$)$ & 0 & 2.11 (0.01 to 19.70$)$ \\
\hline Bones and joints & 4 & $0.53(0.14$ to 1.37$)$ & 0 & $0.70(0.00$ to 6.48$)$ \\
\hline External causes & 173 & $0.90(0.77$ to 1.04$)$ & 15 & $0.74(0.41$ to 1.22$)$ \\
\hline Accidents & 110 & $1.05(0.87$ to 1.27$)$ & 7 & $0.64(0.26$ to 1.31$)$ \\
\hline Motor vehicle & 48 & $0.81(0.59$ to 1.07$)$ & 6 & $0.94(0.34$ to 2.04$)$ \\
\hline Suicide & 46 & $0.88(0.65$ to 1.18$)$ & 6 & $1.11(0.41$ to 2.42$)$ \\
\hline
\end{tabular}

${ }^{\star}$ Significant $95 \%$ CI. All ratios are adjusted for age and calendar year; where no cases exist, SMRs and $95 \%$ CIs were calculated assuming an $\mathrm{n}=0.5$. $\mathrm{HD}=$ heart disease; $\mathrm{ASHD}=$ atherosclerotic heart disease; $\mathrm{w} / \mathrm{CHD}=$ with congestive heart failure; $\mathrm{AHD}=$ atherosclerotic heart disease without congestive heart failure. 
Table 4 Male and female applicators: cancer mortality SMR

\begin{tabular}{|c|c|c|c|c|}
\hline \multirow[b]{2}{*}{ Cause of death } & \multicolumn{2}{|l|}{ Male } & \multicolumn{2}{|l|}{ Female } \\
\hline & Observed $n$ & Florida SMR (95\% CI) & Observed $n$ & Florida SMR $(95 \%$ CI) \\
\hline Malignant neoplasms & 498 & $0.78(0.72 \text { to } 0.86)^{\star}$ & 34 & $0.58(0.40 \text { to } 0.81)^{\star}$ \\
\hline Mouth or pharynx & 7 & $0.47(0.19 \text { to } 0.97)^{\star}$ & 1 & $0.74(0.01$ to 4.11$)$ \\
\hline Digestive & 113 & $0.83(0.68$ to 1.00$)$ & 11 & $0.86(0.43$ to 1.54$)$ \\
\hline Oesophagus & 11 & $0.82(0.41$ to 1.47$)$ & 0 & $0.41(0.00$ to 3.83$)$ \\
\hline Stomach & 11 & $0.69(0.35$ to 1.24$)$ & 0 & $0.34(0.00$ to 3.13$)$ \\
\hline Large intestine & 42 & $0.81(0.59$ to 1.10$)$ & 7 & $1.44(0.58$ to 2.97$)$ \\
\hline Rectum & 7 & $0.78(0.31$ to 1.60$)$ & 1 & $1.19(0.02$ to 6.63$)$ \\
\hline Liver & 16 & $1.23(0.71$ to 2.01$)$ & 0 & $0.41(0.00$ to 3.82$)$ \\
\hline Pancreas & 24 & $0.83(0.53$ to 1.24$)$ & 2 & $0.74(0.08$ to 2.69$)$ \\
\hline Respiratory & 182 & $0.87(0.75$ to 1.01$)$ & 9 & $0.47(0.22$ to 0.90$)$ \\
\hline Larynx & 2 & $0.33(0.04$ to 1.18$)$ & 0 & $0.90(0.00$ to 8.41$)$ \\
\hline Lung & 180 & $0.89(0.76$ to 1.03$)$ & 9 & $0.49(0.22 \text { to } 0.93)^{\star}$ \\
\hline Bone & 3 & $2.72(0.55$ to 7.96$)$ & 0 & $4.45(0.01$ to 42.29$)$ \\
\hline Skin & 15 & $1.18(0.66$ to 1.94$)$ & 0 & $0.41(0.00$ to 3.81$)$ \\
\hline Bladder & 7 & $0.65(0.26$ to 1.33$)$ & 0 & $0.49(0.00$ to 4.55$)$ \\
\hline Kidney & 13 & $1.09(0.58$ to 1.86$)$ & 2 & $1.80(0.20$ to 6.49$)$ \\
\hline Eye & 3 & $4.67(0.94$ to 13.66$)$ & 0 & 8.33 (0.03 to 77.70$)$ \\
\hline Brain or central nervous system & 22 & $1.34(0.84$ to 2.03$)$ & 1 & $0.65(0.01$ to 3.60$)$ \\
\hline All lymphopoietic & 41 & $0.81(0.58$ to 1.10$)$ & 3 & $0.62(0.12$ to 1.80$)$ \\
\hline Lymphosarcoma & 2 & $0.54(0.06$ to 1.94$)$ & 0 & $1.45(0.00$ to 13.54$)$ \\
\hline Hodgkin's disease & 2 & $0.88(0.10$ to 3.17$)$ & 0 & $2.19(0.01$ to 20.44$)$ \\
\hline Leukaemia & 19 & $1.29(0.78$ to 2.02$)$ & 2 & $1.42(0.16$ to 5.12$)$ \\
\hline Other lymphatic & 18 & $0.61(0.36 \text { to } 0.96)^{\star}$ & 1 & 0.35 (0.01 to 1.95$)$ \\
\hline Soft tissue sarcoma & 0 & $0.31(0.00$ to 1.71$)$ & 0 & $1.74(0.01$ to 16.26$)$ \\
\hline \multicolumn{5}{|l|}{ Male and female cancers: } \\
\hline Prostate & 64 & $2.38(1.83 \text { to } 3.04)^{\star}$ & & \\
\hline Testis & 1 & $1.05(0.01$ to 5.81$)$ & & \\
\hline Breast & 0 & $0.01(0.00$ to 0.08$)$ & 4 & $0.76(0.20$ to 1.94$)$ \\
\hline All genital & & & 2 & $0.75(0.08$ to 2.72$)$ \\
\hline Cervix & & & 1 & $1.32(0.02$ to 7.34$)$ \\
\hline Uterus & & & 1 & $0.94(0.01$ to 5.22$)$ \\
\hline Other genital & & & 1 & 0.63 (0.01 to 3.49$)$ \\
\hline
\end{tabular}

*Significant 95\% CI; all ratios are adjusted for age and calendar year; where no cases exist, SMRs (95\% CIs) were calculated assuming an $\mathrm{n}=0.5$.

With the exception of pneumonia and ulcers, the other non-cancer causes of death were all lower than or equal to those of the population of Florida. In particular, causes of death associated with exposure to tobacco and alcohol were lower or not present; there were no cases of cirrhosis or emphysema. The greatest single cause of death was from circulatory diseases (27\%), although substantially less than among the male applicators; the SMR was significantly lower for all the diseases of the circulatory system. Nervous system disease and external causes of death were lower, but not significantly.

The SMR for all malignancies among female applicators was significantly lower than among the general population of Florida $(0.58(0.40$ to 0.81$)$ ). Most cancer mortalities were lower for the female pesticide applicators than for the population of Florida. Cancers associated with tobacco exposure were significantly lower (res-

Table 5 All, male, and female applicators: overall SMR by calendar year of first licence

\begin{tabular}{lrl}
\hline Licence year & Observed $n$ & Florida SMR $(95 \%$ CI $)$ \\
\hline All applicators: & & \\
1975-1979 & 1327 & $0.70(0.66 \text { to } 0.74)^{\star}$ \\
$1980-84$ & 364 & $0.73(0.66 \text { to } 0.81)^{\star}$ \\
$1985-89$ & 142 & $0.59(0.50 \text { to } 0.69)^{\star}$ \\
$1990-94$ & 22 & $0.39(0.34 \text { to } 0.54)^{\star}$ \\
All men: & & \\
$1975-79$ & 1270 & $0.72(0.68 \text { to } 0.76)^{\star}$ \\
$1980-84$ & 341 & $0.77(0.79 \text { to } 0.85)^{\star}$ \\
$1985-89$ & 127 & $0.60(0.50 \text { to } 0.72)^{\star}$ \\
$1990-94$ & 20 & $0.39(0.24 \text { to } 0.60)^{\star}$ \\
All women: & & \\
$1975-79$ & 57 & $0.43(0.32 \text { to } 0.55)^{\star}$ \\
$1980-84$ & 23 & $0.45(0.29 \text { to } 0.68)^{\star}$ \\
$1985-89$ & 15 & $0.50(0.28 \text { to } 0.82)^{\star}$ \\
$1990-94$ & 2 & $0.42(0.05 \text { to } 1.51)^{\star}$ \\
\hline
\end{tabular}

* Significant $95 \%$ CI. All ratios are age adjusted. piratory (0.47 (0.22 to 0.90)) and lung (0.49 $(0.22$ to 0.93$)))$. Female cancers were nonsignificantly lower in the pesticide applicators than the general population of Florida (breast $(0.76(0.20$ to 1.94$))$ and all genital $(0.75(0.08$ to 2.72)) except for cervical cancer, which was higher (1.32 (0.02-7.34)), but this was not significant and was based on one case. The exceptions to this were increased cancer mortalities for kidney, large intestine, and leukaemia (non-significant, and based on very small numbers).

\section{EXPOSURE}

Most of the cohort (54\%) had obtained their pesticide licence by 1984 with 39 (13.19) as the mean (SD) age of licence; the mean number of years licensed for the whole cohort was 6.93 (4.27), with a range from 1 month to 19.64 years. The total number of person-years for the cohort was 320250 from 1 January 1975 to 31 December 1993.

The SMRs for overall mortality by the calendar year of first licence in 5 year groupings are consistently and significantly less than that of the population of Florida (table 5). However, there is an apparent trend of decreasing mortality from the earliest years of licence (1975-9: 0.70 (0.66 to 0.74)) to the most recent (1990-4: 0.39 (0.34 to 0.54)), despite age adjustment. A similar pattern was found for prostate cancer and external causes of mortality; similar results and trends are found by sex subgroups; lung cancer did not show this pattern for either the sex or licence subpopulations (not shown).

For the overall mortality by numbers of years licensed in 4 year groupings (table 6 ), there was 
Table 6 All, male, and female applicators: overall mortality and prostate cancer overall SMR by years of licence

\begin{tabular}{|c|c|c|}
\hline Years of licence & Observed number & Florida SMR (95\% CI) \\
\hline \multicolumn{3}{|c|}{ Overall mortality } \\
\hline \multicolumn{3}{|c|}{ All applicators: } \\
\hline $0 \leqslant 4$ & 63 & $0.64(0.49 \text { to } 0.82)^{\star}$ \\
\hline $4 \leqslant 8$ & 743 & $0.86(0.80 \text { to } 0.93)^{\star}$ \\
\hline $8 \leqslant 12$ & 900 & $0.74(0.69 \text { to } 0.79)^{\star}$ \\
\hline $12 \leqslant 16$ & 115 & $0.42(0.35 \text { to } 0.51)^{\star}$ \\
\hline $16 \leqslant 20$ & 33 & $0.15(0.10 \text { to } 0.21)^{\star}$ \\
\hline \multicolumn{3}{|l|}{ All men: } \\
\hline $0 \leqslant 4$ & 57 & $0.66(0.50 \text { to } 0.85)^{\star}$ \\
\hline $4 \leqslant 8$ & 696 & $0.91(0.84 \text { to } 0.98)^{\star}$ \\
\hline $8 \leqslant 12$ & 859 & $0.77(0.72 \text { to } 0.82)^{\star}$ \\
\hline $12 \leqslant 16$ & 113 & $0.44(0.36 \text { to } 0.53)^{\star}$ \\
\hline $16 \leqslant 20$ & 32 & $0.15(0.10 \text { to } 0.21)^{\star}$ \\
\hline \multicolumn{3}{|l|}{ All women: } \\
\hline $0 \leqslant 4$ & 6 & $0.51(0.19$ to 1.11$)$ \\
\hline $4 \leqslant 8$ & 47 & $0.50(0.36 \text { to } 0.66)^{\star}$ \\
\hline $8 \leqslant 12$ & 41 & $0.44(0.32 \text { to } 0.60)^{\star}$ \\
\hline $12 \leqslant 16$ & 2 & $0.15(0.02 \text { to } 0.53)^{\star}$ \\
\hline $16 \leqslant 20$ & 1 & $0.17(0.01 \text { to } 0.93)^{\star}$ \\
\hline \multicolumn{3}{|c|}{ Prostate cancer mortality: } \\
\hline \multicolumn{3}{|c|}{ All men: } \\
\hline $0 \leqslant 4$ & 21 & $2.59(1.60 \text { to } 3.96)^{\star}$ \\
\hline $4 \leqslant 8$ & 37 & $2.78(1.95 \text { to } 3.83)^{\star}$ \\
\hline $8 \leqslant 12$ & 5 & $1.83(0.59$ to 4.28$)$ \\
\hline $12 \leqslant 16$ & 1 & $0.49(0.01$ to 2.74$)$ \\
\hline $16 \leqslant 20$ & 0 & \\
\hline \multicolumn{3}{|c|}{ Male applicators 1975 to 9 : } \\
\hline $0 \leqslant 4$ & 9 & $2.58(1.18 \text { to } 4.89)^{\star}$ \\
\hline $4 \leqslant 8$ & 36 & $2.90(2.03 \text { to } 4.01)^{\star}$ \\
\hline $8 \leqslant 12$ & 5 & 2.15 (0.67 to 4.88$)$ \\
\hline $12 \leqslant 16$ & 1 & $0.48(0.02$ to 2.69$)$ \\
\hline $16 \leqslant 20$ & 0 & \\
\hline
\end{tabular}

* Significant $95 \%$ CI. All ratios are age and calendar year adjusted.

an inverse dose-response relation in which the apparent trend is of decreasing risk with increasing years of licence, from the fewest years of licence $(0-4,0.64(0.49$ to 0.82$))$ to the greatest number (16-20, $0.15(0.10$ to 0.21$)$ ). Similar results and trends were seen by sex and licence subgroup for overall mortality, external causes of death, and lung cancer (not shown). Although similar results were present for pros- tate cancer for the entire cohort; however, additional analysis performed for the earliest subcohort from 1975-9 suggested that there was an initial positive dose-response with increasing risk of prostate cancer with increasing years of exposure.

PRIVATE (FARMERS) MALE APPLICATORS

Only male applicators were included in these subpopulation analyses due to the relatively few female applicators in each licence subpopulation. There were 20505 private (farmer) male applicators with $1527(81 \%)$ of the entire cohort deaths. The SMR results for non-cancer and cancer causes of mortality for all private (farmer) male applicators compared with the population of Florida are presented in tables 7 and 8.

Similar to the entire cohort, most of the overall mortalities for the private male applicators were lower, often significantly, than for the population of Florida. Most of the cancer mortalities were lower than those for the population of Florida, including respiratory and lung cancers related to tobacco. Despite the few cases, mortalities from cancers of the eye were significantly increased (5.52 (1.11 to 16.12$)$ ). Mortality from prostate cancer was significantly increased (2.56 (1.96 to 3.29)); there were no deaths from testicular cancer. Also, mortalities from leukaemia, and cancer of the bone, the brain, and the central nervous system were all increased, but not significantly.

COMMERCIAL AND PUBLIC MALE APPLICATORS

There were 9650 commercial and public male applicators with $250(13 \%)$ of the cohort deaths. Of these combined male applicators, 6936 were commercial $(72 \%)$ and 2714 were public $(28 \%)$. The SMR results for non-cancer

Table 7 Male private (farmer) applicators and commercial and public applicators: overall and non-cancer SMR

\begin{tabular}{|c|c|c|c|c|}
\hline \multirow[b]{2}{*}{ Cause of death } & \multicolumn{2}{|l|}{ Private } & \multicolumn{2}{|c|}{ Commercial and public } \\
\hline & Observed $n$ & Florida SMR (95\% CI) & Observed $n$ & Florida SMR $(95 \%$ CI) \\
\hline Overall & 1527 & $0.71(0.68 \text { to } 0.75)^{\star}$ & 250 & $0.70(0.62 \text { to } 0.79)^{\star}$ \\
\hline Infectious diseases & 22 & $0.47(0.30 \text { to } 0.72)^{\star}$ & 13 & 0.64 (0.34 to 1.09$)$ \\
\hline Tuberculosis & 2 & $0.79(0.09$ to 2.85$)$ & 0 & $0.60(0.00$ to 1.30$)$ \\
\hline Allergic endocrine & 28 & $0.58(0.39 \text { to } 0.84)^{\star}$ & 4 & $0.41(0.11$ to 1.06$)$ \\
\hline Diabetes & 23 & $0.64(0.40 \text { to } 0.96)^{\star}$ & 3 & $0.45(0.09$ to 1.31$)$ \\
\hline Diseases of blood & 6 & $0.94(0.34$ to 2.04$)$ & 0 & $0.30(0.00$ to 1.50 \\
\hline Mental & 9 & $0.53(0.24$ to 1.00$)$ & 1 & $0.26(0.01$ to 1.46$)$ \\
\hline Nervous system & 30 & $1.20(0.81$ to 1.71$)$ & 4 & $0.91(0.24$ to 2.33$)$ \\
\hline Circulatory system & 686 & $0.87(0.81 \text { to } 0.94)^{\star}$ & 79 & $0.74(0.59 \text { to } 0.93)^{\star}$ \\
\hline Rheumatic HD & 3 & $0.38(0.08$ to 1.11$)$ & 2 & $1.62(0.18$ to 5.84$)$ \\
\hline ASHD (w/CHD) & 446 & $0.99(0.90$ to 1.09$)$ & 52 & $0.86(0.64$ to 1.13$)$ \\
\hline AHD & 480 & $0.95(0.87$ to 1.04$)$ & 56 & 0.83 (0.63 to 1.07$)$ \\
\hline Central nervous system vascular & 79 & $0.81(0.64$ to 1.01$)$ & 11 & $0.82(0.41$ to 1.47$)$ \\
\hline Respiratory diseases & 49 & $0.67(0.50 \text { to } 0.89)^{\star}$ & 4 & $0.36(0.10 \text { to } 0.93)^{\star}$ \\
\hline Pneumonia & 17 & $0.56(0.33 \text { to } 0.90)^{\star}$ & 2 & $0.44(0.05$ to 1.59$)$ \\
\hline Emphysema & 13 & $0.81(0.43$ to 1.39$)$ & 0 & $0.25(0.00$ to 1.25$)$ \\
\hline Asthma & 1 & $0.28(0.01$ to 1.57$)$ & 0 & $0.14(0.01$ to 1.05$)$ \\
\hline Digestive diseases & 50 & $0.67(0.50 \text { to } 0.89)^{\star}$ & 5 & $0.32(0.10 \text { to } 0.75)^{\star}$ \\
\hline Ulcers & 5 & $1.04(0.34$ to 2.43$)$ & 1 & $1.37(0.02$ to 7.64$)$ \\
\hline Cirrhosis & 22 & $0.53(0.33 \text { to } 0.80)^{\star}$ & 3 & $0.31(0.06 \text { to } 0.89)^{\star}$ \\
\hline Genitourinary & 13 & $0.67(0.35$ to 1.14$)$ & 4 & $1.48(0.40$ to 3.79$)$ \\
\hline Skin diseases & 1 & $0.47(0.01$ to 2.62$)$ & 1 & $0.76(0.01$ to 4.23$)$ \\
\hline Bones and joints & 3 & $0.49(0.10$ to 1.42$)$ & 0 & $0.15(0.00$ to 1.20$)$ \\
\hline External causes & 130 & $0.91(0.76$ to 1.09$)$ & 43 & $0.84(0.61$ to 1.14$)$ \\
\hline Accidents & 81 & $1.05(0.83$ to 1.30$)$ & 29 & $1.08(0.72$ to 1.55$)$ \\
\hline Motor vehicle & 34 & $0.79(0.54$ to 1.10$)$ & 14 & $0.86(0.47$ to 1.44$)$ \\
\hline Suicide & 35 & $0.90(0.63$ to 1.26$)$ & 11 & $0.82(0.41$ to 1.47$)$ \\
\hline
\end{tabular}

* Significant $95 \%$ CI. All ratios are adjusted for age and calendar year; where no cases exist, SMRs $95 \%$ CIs were calculated assuming an $\mathrm{n}=0.5$.

$\mathrm{HD}=$ heart disease $\mathrm{ASHD}=$ atherosclerotic heart disease $; \mathrm{w} / \mathrm{CHD}=$ with congestive heart failure $\mathrm{AHD}=$ atherosclerotic heart disease without congestive heart failure. 
Table 8 Male private (farmer) applicators and commercial and public applicators: cancer SMR

\begin{tabular}{|c|c|c|c|c|}
\hline \multirow[b]{2}{*}{ Cause of death } & \multicolumn{2}{|l|}{ Private } & \multicolumn{2}{|c|}{ Commercial and public } \\
\hline & Observed $n$ & Florida SMR (95\% CI) & Observed $n$ & Florida SMR $(95 \%$ CI) \\
\hline Malignant neoplasms & 416 & $0.77(0.70 \text { to } 0.85)^{\star}$ & 82 & $0.83(0.66$ to 1.03$)$ \\
\hline Mouth or pharynx & 5 & $0.41(0.13 \text { to } 0.95)^{\star}$ & 2 & $0.78(0.09$ to 2.83$)$ \\
\hline Digestive & 92 & $0.79(0.64 \text { to } 0.97)^{\star}$ & 21 & $1.06(0.65$ to 1.61$)$ \\
\hline Oesophagus & 7 & $0.63(0.25$ to 1.29$)$ & 4 & $1.83(0.49$ to 4.69$)$ \\
\hline Stomach & 8 & $0.59(0.26$ to 1.17$)$ & 3 & $1.26(0.25$ to 3.69$)$ \\
\hline Large intestine & 36 & $0.81(0.57$ to 1.12$)$ & 6 & $0.84(0.31$ to 1.82$)$ \\
\hline Rectum & 6 & $0.78(0.29$ to 1.71$)$ & 1 & $0.74(0.01$ to 4.11$)$ \\
\hline Liver & 13 & $1.18(0.63$ to 2.02$)$ & 3 & $1.52(0.31$ to 4.43$)$ \\
\hline Pancreas & 21 & $0.85(0.53$ to 1.30$)$ & 3 & $0.72(0.15$ to 2.11$)$ \\
\hline Respiratory & 148 & $0.84(0.71 \text { to } 0.99)^{\star}$ & 34 & $1.03(0.71$ to 1.44$)$ \\
\hline Larynx & 1 & $0.20(0.01$ to 1.09$)$ & 1 & $0.98(0.01$ to 5.46$)$ \\
\hline Lung & 147 & $0.86(0.73$ to 1.01$)$ & 33 & $1.04(0.72$ to 1.46$)$ \\
\hline Bone & 2 & $2.29(0.26$ to 8.27$)$ & 1 & $4.38(0.06$ to 24.35$)$ \\
\hline Skin & 12 & $1.17(0.61$ to 2.05$)$ & 3 & $1.19(0.24$ to 3.49$)$ \\
\hline Bladder & 7 & $0.74(0.30$ to 1.52$)$ & 0 & $0.21(0.00$ to 1.04$)$ \\
\hline Kidney & 10 & $0.99(0.48$ to 1.83$)$ & 3 & $1.59(0.32$ to 4.65$)$ \\
\hline Eye & 3 & $5.52(1.11 \text { to } 16.12)^{\star}$ & 0 & $1.5(0.00$ to 11.50$)$ \\
\hline Brain or central nervous system & 17 & $1.28(0.74$ to 2.04$)$ & 5 & $1.62(0.52$ to 3.79$)$ \\
\hline All lymphopoietic & 36 & $0.85(0.60$ to 1.18$)$ & 5 & $0.61(0.20$ to 1.42$)$ \\
\hline Lymphosarcoma & 1 & $0.32(0.01$ to 1.76$)$ & 1 & $1.80(0.02$ to 10.04$)$ \\
\hline Hodgkin's disease & 2 & $1.13(0.13$ to 4.09$)$ & 0 & $0.80(0.00$ to 1.95$)$ \\
\hline Leukaemia & 16 & $1.31(0.75$ to 2.12$)$ & 3 & $1.23(0.25$ to 3.61$)$ \\
\hline Other lymphatic & 17 & $0.68(0.40$ to 1.09$)$ & 1 & $0.21(0.01$ to 1.18$)$ \\
\hline Soft tissue sarcoma & 0 & $0.31(0.00$ to 1.71$)$ & 0 & $0.65(0.00$ to 1.91$)$ \\
\hline Male cancers only: & & & & \\
\hline Prostate & 62 & $2.56(1.96 \text { to } 3.29)^{\star}$ & 2 & $0.73(0.08$ to 2.65$)$ \\
\hline Testis & 0 & & 1 & $4.32(0.06$ to 24.02$)$ \\
\hline
\end{tabular}

* Significant $95 \%$ CI. All ratios are age and calendar year adjusted; where no cases exist, SMRs (95\% CIs) were calculated assuming an $n=0.5$.

and cancer causes of mortality for all commercial and public male applicators compared with all the population of Florida are presented in tables 7 and 8 .

Similar to the entire cohort, most of the mortalities for the commercial and public male applicators were lower than for the population of Florida, including respiratory and lung mortalities related to tobacco. Although there were few cases, mortalities from cancer of the bone, brain, and central nervous system, and leukaemia were increased, although not significantly. Mortality from testicular cancer was nonsignificantly increased with one case (4.32 (0.06 to 24.02$)$ ), whereas mortality from prostate cancer was not increased. As opposed to the private male applicators, mortalities from cancer of the oesophagus, kidney, liver, and stomach, as well as lymphosarcoma, were increased, although not significantly.

\section{Discussion}

In general, this is a healthy cohort of men and women who have been relatively recently exposed to restricted use pesticides through their occupation. Compared with the general population of Florida, these pesticide applicators are generally less likely to die from various specific chronic diseases, including the cardiovascular diseases. In particular, these workers are less likely to die from the chronic diseases associated with the use of tobacco and alcohol.

\section{DATA LIMITATIONS}

As discussed above, these analyses have many of the data limitations found in previous epidemiological studies of workers exposed to pesticides. Limitations include issues of the healthy worker effect, exposure measures, duration of follow up, and loss to follow up. Over $50 \%$ of the study population was followed up for more than 14 years; however, given the mortality end points, additional follow up is needed to evaluate the health outcomes of this cohort. The use of the population of Florida as the major comparison population is appropriate for geographical and logistic reasons. However, in occupational studies, the use of a general population for comparison must inherently raise the issue of the healthy worker effect, even for chronic diseases-such as cancer. ${ }^{23} 252728$

As with many previous studies, individual and cohort specific confounding - such as smoking - and detailed pesticide exposure information were not obtained for this cohort. The occupational exposure measures are relatively crude and non-specific, based on the licence calendar year and years of exposure, as well as licence subgroup and certification subcategory. Therefore, licence serves as a surrogate measure for exposure; this assumes that the applicator uses the restricted chemicals throughout the 4 year licence period; that in the case of older people, the applicator did not apply before the beginning of the licence programme (before the beginning of the cohort); that the applicator is actually applying the restricted use pesticides rather than acting in a purely supervisory role as each licensed applicator may oversee up to 15 other people. The lack of these data is an important limitation on any conclusions which could be drawn from these analyses.

MEN

Among male applicators, the most consistently increased cancer mortalities were of the testicles and prostate. In a separate study of cancer incidence in this same cohort and different from the literature, the incidences of these cancers were increased in both the licence subcohorts (private $v$ commercial and public). ${ }^{29}$ This suggests the possibility that 
previous mortality studies may have underestimated the risks of these cancers. ${ }^{6}{ }^{10}{ }^{30-33}$ It is possible that these relatively healthy working populations are more likely to die from prostate cancer exactly because they do not die of other causes so common in the general population.

As already mentioned, an increased risk of prostate cancer is a consistent finding in most previous farmer studies. This is at odds with current theories about the possible protective effects of vitamin $\mathrm{D}$, given the presumed high occupational exposure to ultraviolet light of agricultural workers and their reportedly high rates of skin cancer. ${ }^{34}$ As another possible explanation, exposures to the organochlorine pesticides as possible oestrogen analogues and their possible relation to worldwide increases in testicular cancer and prostate cancer are also of interest. Male alligators in Florida with heavy exposure to organochlorine were found to be reproductively incompetent, and, although recent reports have raised the question of a significant overall worldwide decrease in human sperm counts and increases in cryptorchidism, possibly related to use of pesticide. ${ }^{35-37}$ More recently, some of the organochlorines have been shown in animal models to be antiandrogens. ${ }^{37}$

Eye and bone cancers were also increased among the male applicators; the few cases makes definitive interpretation difficult, although similar increases have been seen in other studies. Compared with other studies, the risks of leukaemia and brain cancer were only slightly increased in the mortality study. ${ }^{6} 303138-41$

There were no confirmed cases of soft tissue sarcoma in this cohort of pesticide applicators, and non-Hodgkin's lymphoma was not higher in any of the subpopulations examined. These findings are at odds with the previously published literature associating the use of the phenoxy herbicides with an increased risk of both non-Hodgkin's lymphoma and soft tissue sarcoma. ${ }^{20} 42-44$

WOMEN

The number of female applicators was small, as were the numbers of deaths in this subpopulation. They were also significantly younger and had significantly lower exposure time than their male counterparts. Although comparisons cannot be made across SMRs, nevertheless as a whole the female applicators seem to be healthier than the male applicators; this may be due to their lower exposure, as well as the unstable risk measurements due to the few female applicators.

Mortality from breast cancer was not significantly increased in any of the subpopulations, despite the presence of multiple organochlorine pesticides on the restricted pesticide list. Very few studies exist of occupational exposure to organochlorines in women with which to test current hypotheses about the possible aetiological relation between exposure to organochlorines (as oestrogen analogues) and the increased risk of breast cancer. ${ }^{4546}$

Mortality from cervical cancer was nonsignificantly increased in all women; in a sepa- rate study of cancer incidence of the same cohort, incidence of cervical cancer was significantly increased with increasing risk associated with increased number of years of exposure. ${ }^{29}$ The fact that the incidence of cervical cancer was increased in our study but not in previous mortality studies is consistent with existing availability of excellent screening and treatment. Little has been published on female pesticide applicators in general; therefore, although a small subpopulation, these findings are of interest and deserve to be studied further. ${ }^{212247}$

PRIVATE (FARMERS) V COMMERCIAL AND PUBLIC APPLICATORS

Prostate cancer was significantly increased for the farmers whereas mortality from testicular cancer was non-significantly increased for the commercial and public pesticide applicators. In the separate study of cancer incidence of the same cohort, incidences of both testicular and prostate cancer were significantly increased for both licence subcategories. ${ }^{29}$ Prostate cancer has been found to be increased in farmers in many studies, and increased incidence of testicular cancer was found in Swedish pesticide applicators, as well as limited increased mortality in other groups. ${ }^{32}{ }^{48-54}$ Many of the studies of pesticide applicators have been studies of cancer mortality rather than cancer incidence. This is important as both testicular and prostate cancers have much higher incidences than mortalities due to excellent treatment available for the testicular cancer and the general slow progression of prostate cancer. This does not explain why the subpopulations would have different mortalities but similar incidences, unless the cancers are more aggressive in the licence subcategories, or there are access to care issues, possibly a diagnostic bias, or relative lack of competing causes of death.

Finally, as opposed to the increased risk for lung cancer found among several cohorts of pesticide applicators (including a separate cohort of structural non-agricultural applicators in Florida), mortality from lung cancer was not increased among either subgroup; nor was there any evidence of any dose response of exposure. ${ }^{49} 50$ 55-57

As with many of the existing studies on occupational exposure to pesticides, this cohort of Florida pesticide applicators deserves further research. Completing the follow up process for the $8 \%$ of the cohort which is lost to follow up would be worthwhile, as well as extending the number of years of follow up for the entire cohort in the future. In particular, detailed individual exposure information for both pesticides and confounders should be sought. Additional studies of the up to 15 workers supervised by an individual licenced pesticide applicator are also recommended as these people may be even more highly exposed than the licenced supervisor.

This study would not have been possible without the cooperation and personnel of the Florida Department of Agriculture and Consumer Services, the Florida Cancer Data System and the Florida Vital Statistics of the Florida Department of Health, the Florida Health Care Administration, 
the Florida Motor Vehicles Registry, the Healthcare Finance Administration (HCFA), and the University of Miami School of Medicine. This work was supported in part by a Career Devel-
opment Award (No 1-KO1-OHOO125) from the National opment Award (No 1-KO1-OHOO125) from the National Institute of Occupational Safety and Health (NIOSH). This
work was presented in part at the American Public Health work was presented in part at the American Public Health
Association Annual Conference in Indianapolis, Indiana in Association Ann
November 1997.

1 Fleming LE, Herzstein JA. Emerging issues in pesticide health studies. Occup Med 1997;12:387-97.

2 World Health Organization. Public health impact of pesticides used in agriculture. Geneva: WHO, 1990.

3 Jeyaratnam J. Health problems of pesticide usage in the third world. Br f Ind Med 1985;42:505-6.

4 Moses M, Johnson ES, Anger WK, et al. Environmental equity and pesticide exposure. Toxicol Ind Health 1993;9: 914-59.

5 International Agency for Research on Cancer. Occupational exposure in insecticide application and some pesticides IARC Monogr Eval Carcinog Risk Chem Hum 1991;53:1587.

6 Maroni M, Fait A. Health effects in man from long term

exposure to pesticides. Toxicology 1993;78:1-180.
7 Maddy KT, Edmiston S, Richmond D. Illness, injuries and deaths from pesticide exposures in California 1949-88. Rev Environ Contam Toxicol 1990;114:57-123.

8 Levine RS, Doull J. Global estimates of acute pesticide morbidity and mortality. Rev Environ Contam Toxicol 1992;129: $29-50$

9 O'Malley M. Clinical evaluation of pesticide exposure and poisonings. Lancet 1997;349:1161-6.

10 Council on Scientific Affairs. Cancer risk of pesticides in agricultural workers. $\mathcal{F A M A} \quad 1988 ; 260: 959-66$.

11 Blair A, Zahm SH. Agricultural exposures and cancer. Environ Health Perspect 1995;103(suppl 8):205-8.

12 Weisenburger DD. Human health and agricultural use. Hum Pathol 1993;24:571-6.

13 Doe JE, Paddle GM. The evaluation of carcinogenic risk to humans: occupational exposures in the spraying and appli297-308.

14 Blondell JM. Problems encountered in the design of epidemiologic studies of cancer in pesticide users. Med Lav miologic studies

15 Blair A, Hoar Zahm S. Methodologic issues in exposure assessment for case control studies of cancer and hericides. Am 9 Ind Med 1990;18:285-93.

16 Blair A, Hoar Zahm S. Herbicides and cancer: a review and discussion of methodologic issues. Recent Results Cancer Res 1990;120:132-45.

17 Cordes DH, Foster Rea D, eds. Health hazards of farming Occup Med 1991;6:327-550.

18 Munro IC, Carlo GL, Orr JC, et al. A comprehensive, integrated review and evaluation of the scientific evidence relating to the safety of the herbicide $2.4 \mathrm{D}$. Fournal of the American Collage of Toxicology 1992;11:561-661.

19 Richardson RJ. Assessment of the neurotoxic potential of Chlorpyrifos relative to other organophosphorus compounds: a critical review of the literature. 7 Toxicol Environ Health 1995;44:135-65.

20 Cantor KP, Blair A, Everett G, et al. Pesticides and other agricultural risk factors for non-Hodgkin's lymphoma agricultural risk factors for non-Hodgkin's lymphoma 2447-55.

$21 \mathrm{McDuffie} H \mathrm{H}$. Women at work: agriculture and pesticides. $\mathcal{F}$ Occup Environ Med 1994;36:1240-6.

22 Alavanj a MC, Akland G, Baird D, et al. Cancer and non-cancer risk to women in agriculture and pest control the Agricultural health study. 7 Occup Environ Med 1994;36:1247-50

23 Breslow NE, Day NE. Statistical methods in cancer research Vol ii. The design and analysis of cohort studies. Lyon: International Agency for Research on Cancer, 1987.

24 Rothman KJ, Boice JD. Epidemiologic analyses with a programmable calculator. Washington, DC: United States Department of Health, 1979. (NIH Publication \#791649.)

25 Checkoway H, Pearce NE, Crawford-Brown DJ. Research methods in occupational epidemiology. New York: Oxford University Press, 1989

26 Kelsey JL, Whittemore AS, Evans AS, et al. Methods in observational epidemiology. New York: Oxford University Press,

27 Monson RR. Occupational epidemiology, 2nd edition. Boca Raton: CRC Press, 1990,
28 Kleinbaum DG, Kupper LL, Muller KE. Applied regression analysis and other multivariable methods. Boston: PWSKENT, 1988

29 Fleming LE. A study of Florida pesticide applicators. [PhD dissertation.] Newhaven, CT: Yale University, 1997.

30 Blair A, Malker H, Cantor KP, et al. Cancer among farmers. Scand $\mathcal{F}$ Work Environ Health 1985;11:397-407.

31 Burmeister LF. Cancer in Iowa farmers: recent results. Am f Ind Med 1990;18:295-301.

32 McDowall M, Balarajan R. Testicular cancer and employment in agriculture. Lancet 1984;i:510-1.

33 Pearce N, Reif JS. Epidemiologic studies of cancer in agricultural workers. Am f Ind Med 1990;18:133-48.

34 Hanchette CL, Schwartz GG. Geographic patterns of prostate cancer mortality: evidence for a protective effect of ultraviolet radiation. Cancer 1992;70:2861-9

35 Carlsen E, Giwercman A, Keiding N, et al. Evidence for decreasing quality of semen during past 50 years. BfM 992;305:609-13.

36 Strohmer H, Boldizsar A, Plockinger B, et al. Agricultural work and male infertility. Am F Ind Med 1993;24:587-92.

37 Toppari J, Larson JC, Christiansen P, et al. Male reproductive health and environmental xenoestrogens. Environ Health Perspect 1996;104(suppl 4):741-803.

38 Brown LM, Blair A, Gibson R, et al. Pesticide exposures and other agricultural risk factors for leukemia among men in Iowa and Minnesota. Cancer Res 1991;50:6585-91.

39 Morrison HI, Semenciw RM, Morrison D, et al. Brain cancer and farming in western Canada. Neuroepidemiology 1992;11:267-76.

40 Figa-Talamanca I, Mearelli I, Valente P, et al. Cancer mortality in a cohort of rural licensed pesticide users in a province of Rome. Int $\mathcal{F}$ Epidemiol 1993;22:579-83.

41 Figa-Talamanca I, Mearelli I, Valente P. Mortality in a cohort of pesticide applicators in an Urban setting. Int 7 Epidemiol 1993;22:674-6.

42 Johnson ES. Association between soft tissue sarcomas, malignant lymphomas, phenoxy herbicides/chlorophenols: evidence from occupational cohort studies. Fundam Appl Toxicol 1990;14:219-34.

43 Palackdharry CS. The epidemiology of non-Hodgkin's lymphoma: why the increased incidence? Oncology 1994;8: 67-73.

44 Zahm SH, Blair A. Pesticides and non-Hodgkin's lymphoma. Cancer Res 1992;52(suppl):5485s-8s.

45 Wolff MS, Toniolo PG, Lee EW, et al. Blood levels of organochlorine residues and risk of breast cancer. 7 Nat Cancer Inst 1993;85:648-52.

46 Kreiger N, Wolff MS, Hiatt RA, et al. Breast cancer and serum organochlorines: a prospective study among white, black, and Asian women. F Natl Cancer Inst 1994;86:58999.

47 Zahm S, Weisenburger DD, Saal RC, et al. The role of agricultural pesticide use in the development of NonHodgkin's lymphoma in women. Arch Environ Health 1993;48:353-8

48 Wiklund K, Dich J, Holm L-E. Testicular cancer among agricultural workers and licensed pesticide applicators in Sweden. Scand $\mathcal{F}$ Work Environ Health 1986;12:630-1.

49 Blair A, Grauman DJ, Lubin JH, et al. Lung cancer and other causes of death among licensed pesticide applicators. 7 Natl Cancer Inst 1983;71:31-7.

50 Alberghini V, Luberto F, Gobba F, et al. Mortality among male farmers licensed to use pesticides. Med Lav 1991;82: $18-24$

51 Alavanja MCR, Blair A, Merkle S, et al. Mortality among forest and soil conservationists. Arch Environ Health 1989; 44:94-101.

52 Coggon D, Pannett B, Winter PD, et al. Mortality of workers exposed to 2 methyl 4 chlorophenoxyacetic acid. Scand f Work Environ Health 1986;12:488-54.

53 Cantor KP, Booze CF. Mortality among aerial pesticide applicators and flight instructors. Arch Environ Health 1990;45:295-302, and 1991;46:10-116.

54 Swaen GMH, van Vliet C, Slangen JJM, et al. Cancer mortality among licensed herbicide applicators. Scand $\mathcal{F}$ Work Environ Health 1992;18:201-4.

55 Barthel E. Retrospective cohort study on cancer frequency in pesticide exposed male pest control workers. $Z$ Erkrank Amt Org 1986;166:62-8.

56 Pesatori AC, Sontag JM, Lubin JH, et al. Cohort mortality and nested case control study of lung cancer among structural pesticide control workers in Florida (United States). Cancer Causes Control 1994;5:310-8.

57 Wang HH, MacMahon B. Mortality of pesticide applicators. fournal of Occup Med 1979;21:741-4. 